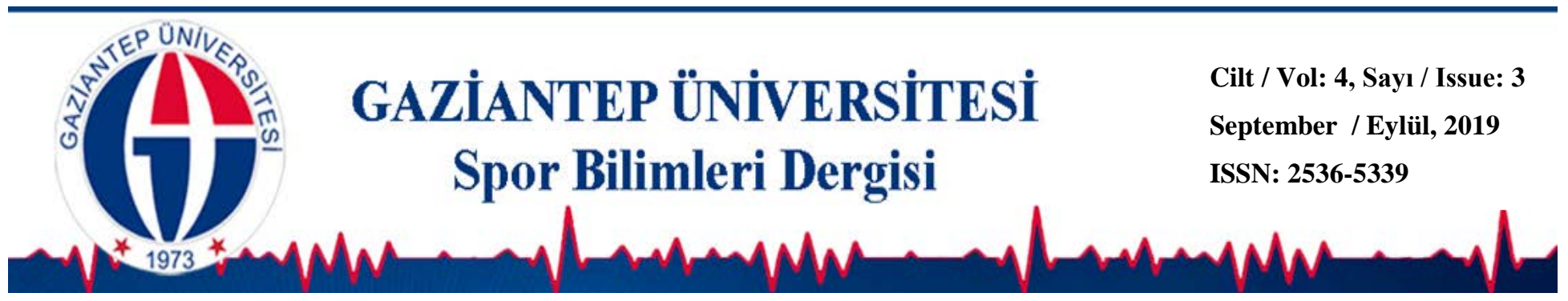

\title{
Doğal Alan Rekreasyonu Öz-Yeterlik Ölçeği: Geçerlik ve Güvenirlik Çalışması
}

\author{
Sırrı Cem DînÇ ${ }^{1 *}$ (iD) \\ Özge YAVAŞ TEZ² \\ ${ }^{1}$ Nevşehir Hacı Bektaş Veli Üniversitesi, Spor Bilimleri ve Teknoloji Yüksekokulu, NEVŞEHİR \\ ${ }^{2}$ Manisa Celal Bayar Üniversitesi, Rekreasyon Anabilim Dalı, MANISA
}

\section{DOI: 10.31680/gaunjss.610544}

Orijinal Makale / Original Article

Geliş Tarihi / Received: 26.08.2019
Kabul Tarihi / Accepted: 06.09.2019

\section{Öz}

Bu araştırmanın amacı; doğal alan rekreasyonu etkinliklerine katılan bireylerin katıldıkları etkinliklere ilişkin öz yeterlik düzeylerini ölçmek amacıyla geliştirilmiş olan Doğal Alan Rekreasyonu Öz-Yeterlik Ölçeği'nin (DARÖYÖORSE) Türkçe'ye adaptasyon çalışmasını yapmaktır. Araştırmanın örneklem grubunu, farklı doğal alan rekreasyonuna katılan 359 birey (kadın $139 \overline{\mathrm{x}}=39.50 \mathrm{ss}=12.13$ yaş; erkek $220 \overline{\mathrm{x}}=41.36 \mathrm{ss}=12.05$ yaş) oluşturmuştur. DARÖYÖ'nün original formu toplam iki alt boyut ve 17 maddeden oluşmaktadır. Elde edilen verilerin analizinde, tanımlayıcı istatistiklere ek olarak madde analizi, Açımlayıcı Faktör Analizi (AFA), Doğrulayıcı Faktör Analizi (DFA), iki yarı test, iç tutarlık katsayıları hesaplanmıştır. AFA sonuçları, maddelerin faktör yük değerlerinin iki alt boyut altında $.59-.87$ aralığında değiştiğini ve toplam varyans \% 67.7'sini karşıladığını göstermiştir. Doğrulayıcı Faktör Analizi (DFA) orijinal formla tutarlı olarak ölçek Türkçe formunun da 2 alt boyut 13 maddeden oluştuğunu, modelin mükemmel ve yeterli uyum indekslerine ulaştığını (x²/sd: 2.38, AGFI: .94 CFI: .96, GFI .91, RMSEA .07)belirlenmiştir. Ölçeğin faktör yüklerinin 0.52-0.89 arasında değiştiği tespit edilmiştir . Ölçeğin Cronbach's Alpha iç tutarlık katsayılarının 0.93 (beceri ve yeterlik) ile 0.83 (haz ve başarma) arasında değiştiği bulunmuştur. Ölçeğin Spearman Brown ve Guttman korelasyon katsayıları ise tek sayılar için (0.80-0.79); çift sayılar için (0.82-0.78) olarak bulunmuştur. Elde edilen sonuçlara göre, Türk kültürüne uyarlanan DARÖYÖ'nün doğal alan rekreasyonuna katılan bireylerin öz yeterlik düzeylerinin belirlenmesi için kullanılabilecek geçerli ve güvenilir bir ölçme aracı olduğu ifade edilebilir.

Anahtar Kelimeler: Doğal alan rekreasyonu, öz yeterlik, geçerlik, güvenirlik

\section{Outdoor Recreation Self-Efficacy: Validity and Reliability Study}

\begin{abstract}
The aim of this study was to adapt the "Outdoor Recreation Self-Efficacy" (ORSE) to measure self-efficacy level of outdoor recreation participants. The sample group consisted of 359 (famale $139 \bar{x}=39.50$ sd=12.13 years; male $220 \bar{x}=41.36 \mathrm{sd}=12.05$ years) participants from different outdoor recreation categories. The original version of the scale consists of 2 sub-dimensions and 17 items. Descriptive statistics, item analysis, Exploratory Factor Analysis (EFA), Confirmatory Factor Analysis (CFA), Split-Half Analysis, Crombach's Alpha analysis were performed to analyze data. EFA showed that the factor structure revealed two sub-dimensions, the factor load values of the items varied between .59 and .87 and covered $67.7 \%$ of the total variance. The CFA results showed that consistent with the original form, the Turkish version of the scale was also consisted of 2 sub-dimensions and a total of 13 items, the model reached perfect and adequate fit indexes ( $x^{2} /$ sd: 2.38 , AGFI: .94 CFI: .96, GFI .91, RMSEA .07)after with the necessary modification procedures. The factor loadings of the scale were ranged between 0.52-0.88. eliability coefficients for the sub-dimensions ranged from 0.93 (skills and competence) and 0.83 (enjoyment and accomplishment). Split-Half correlation coefficients of the scale were found for odd numbers $(0.80-0.78)$ and for even numbers (0.82-0.78). Results finally indicated that ORSE was a valid and reliable measurement tool to be used for measuring the self-efficacy level of Turkish outdoor recreation participants.
\end{abstract}

Key Words: Outdoor recreation, self-efficacy, scale, validity, reliability

\footnotetext{
* Sorumlu Yazar: Sırrı Cem DİNÇ
}

E-mail: scem.dinc@gmail.com 


\section{Giriş}

Son on yılda, açık hava rekreasyonu ve doğa temelli turizmin popülaritesi çarpıcı bir şekilde artmıştır (Cordell, 2008) ve ilişkili faaliyetler gelişmiş ülkelerde modern ve sağlıklı yaşam tarzlarının bir işareti haline gelmiştir (Pröbstl-Haider ve diğ, 2015; Haegeli\&Pröbstl-Haider, 2016). Amerika Kıtası olmak üzere, Avrupa ve Avustralya kıtasında hızıı büyüyen turizm sektörlerinden biridir ve sert macera katılım oranlarının artış eğilimine devam edeceği öngörülmektedir (Outdoor Industry Association, 2013). Bu durum doğa ile insan arasında yeni bir etkileşim yaratma, yorum getirme arayışı olarak yorumlanmalıdır (Demirhan, 1995; Orhun, 1994). Alışılagelmiş şehir yaşantısından zaman ve mekan olarak ayrılan "doğal alan rekreasyonu" yerli literatürde "kırsal rekreasyon" (Karaküçük, 2014) açık alan rekreasyonu (Çelebi, 2002; Karaküçük ve diğ, 2017) ifade edilmiştir. Priest ve Gass (2018) doğal alan rekreasyonunu, hiçbir hayvan ve motor gücü yardımı olmadan tamamen bireyin bilgi, beceri ve kondisyon olmak üzere üç unsurun birleşimi sonucu var olan potansiyelini doğadaki zorluklara karşı kullanma, hayatta kalmak için mücadele etme girişimlerinin gerçekleştirildiği etkinlikler olarak tanımlamıştır.

Literatürde "doğal alan, açık alan vb." şekillerde adlandırılan "outdoor" kavramına ilişkin üzerinde durulması istenen ana temanın doğal ortam olması, doğanın kullanılması ve değerinin bilinmesi ile ilgili olduğu açıklanmıştır (Martin ve diğ., 2006). Aslında kavramın özünde aktivitenin gerçekleştirileceği mekanın açık veya kapalı olmasından ziyade, seçimi yapılan aktivitenin doğal çevre ile ilişki düzeyinin irdelenmesi açısından önem taşır. "Outdoor" kelimesinin karşılığı olarak kullanılan "doğal alan" kavramı, bir nevi "her şeyden uzak" olma hissini bireyde yaşatabilecek ve bireyi içsel olarak doğa ile etkileşime sokabilecek unsurların var olduğu ortamları ifade eder (Bell, 1997).

Doğal alan rekreasyonu sonuçları belirsiz olan deneyimleri üretmek için beceri, yetenek, tercih, geçmiş deneyim ve beklentiler gibi bireysel faktörleri, program hedefleri, faaliyetler, gerçekte var olan ya da algılanan tehlike ve tehditler gibi sosyal ve çevresel faktörleri bir araya getirmektedir (Ewert \& Sibthorp, 2014). Bu nedenle başarılı rekreasyonel deneyimler, programa katılan bireylerin niteliklerini doğru bir şekilde değerlendirip uygun eğlence fırsatlarıyla eşleştirme yeteneğine bağlıdır (Ewert \& Hollenhorst, 1989). Dolayısıyla katılımcının doğada ulaşmak istediği deneyimin kalitesi, etkinliğe ilişkin öz yeterlik düzeyi ile orantılı olabilecektir. Çünkü 
tarihsel süreçte, doğal alan eğitim programları ve araştırmalar katıımdan sağlanan pozitif sonuçların doğruluk nosyonunu inmal ederek öncelikle öz-yeterlilik artışının daha önemli olduğunu ön görmüştür (Jones ve Hinton, 2007). Öz yeterlilikteki bu tek boyutlu bakış açısı öz yeterlikteki artışların refah, başarı ve güven ile ilgili olduğu dikkate alındığında uygun gibi görünmektedir (Propst ve Kessler, 1998).

Öz yeterlik teorisi, bireyin yetkinliklerine ve yeteneklerine olan inançlarının belirli faaliyetlere ve genel olarak hayata katıımı nasıl etkilediğini belirlemek için otuz yılı aşkın bir süredir yaygın olarak kullanılmaktadır. Ayrıca sahip olunan çeşitli deneyimlerin etkinliği nasıl etkileyebileceğini belirlemek amacıyla ölçülmüştür. Daha spesifik olarak, davranışları anlamak, başarıyı açıklamak ve hatta katılımın devam etmesi için öz yeterlikten yararlanılmıştır (Bandura, 1997; Mittelstaedt ve Jones, 2009). Bireyin içinde bulunduğu duruma ilişkin koşulları en iyi şekilde değerlendirerek bu süreci idare etmesi, yönetmesi ve bu sürece ilişkin kendini değerlendirme yeteneğine olan inanç olarak tanımlanan "öz yeterlik" kavramı, öznel bir durumu ifade etmektedir (Bandura, 1990). Bu öznel durum doğa sporları ve macera rekreasyonu açısından da dikkat çekici bir unsur olarak görülmelidir. Bireyde oluşan bu öz yeterlik inancı yapacağı iş veya etkinliğe ilişkin onu harekete geçiren bir dürtü oluşturur ve bu dürtü bireyde hareketin başlangıcı için temel oluşturur. Oluşan bu temel doğrultusunda birey gerçekleştirmeyi düşündüğü iş veya etkinliğe ilişkin ne kadar çaba harcayacağını belirleyerek kafasında bir rota belirler ve bu rota aracılığı ile sonuca ulaşamaya çalışır. İşte bu noktada bireyin becerilerine yönelik öz değerlendirmeleri ve en önemlisi bu becerilere ilişkin algısı önemli rol oynamaktadır (Bandura, 1997; Duman, 2007). Ek olarak öz yeterlik algısı motivasyonu doğrudan etkilediği bilinmektedir. Bireyin becerilerini değerlendirerek kendini yeterli gördüğü etkinlere yoğunlaşığı, aksi bir durum olduğunu durumda ise kaçış yolları aradığı düşünülmektedir. İşte tam da bu noktada öz yeterlik algısının bireyin olumsuz koşullar ile mücadele edebilme derecesinin belirlenmesinde etkin rol oynadığı düşünülmektedir. Bir bireyin öz yeterlik algısı ne kadar yüksek ise zorlu koşullar altında mücadele edebilme çabası da o kadar yüksek olacaktır (Pajares ve Schunk, 2001). Araştırmalar, öz yeterliğin düşük düzeydeki tahminin, kalıcılığı arttırma olasılığı nedeniyle, kabul edilebilir olduğunu iddia eder. Ancak diğer araştırmalar öz yeterlik inancının aşırı şişirilmesi durumunda sonuçların olumsuz olduğu sonucunu ortaya koymuştur (Vancouver, 2012). Öz yeterlilik ve belirli bireylerin performansı 
arasındaki ilişkiye bakıldığında (genel grup performansının aksine) öz yeterlilikteki artışlar performansın düşmesine neden olabilir (Schmidt ve Deshon, 2009; Vancouver ve Kendall, 2006). Öz yeterlik algısı ve bireyin becerilerine olan inancının gelişmesine ilişkin olarak başarılmış deneyimlerin, dolaylı deneyimlerin, sözel olarak ikna etmenin, fizyolojik ve duygusal durumların etkili olduğunu ifade edilmiştir (Bandura,1977; Priest \& Gass, 2018).

Yaşamımızın her alanında olduğu kadar doğa sporları ve macera rekreasyonu açısından da "öz yeterlik" etkinliğin gerçekleştirilmesine ilişkin bireyin başarıya olan inancını etkilemektedir. Öz yeterlik algısı ve bireyin becerilerine olan inancının gelişmesine ilişkin dört unsurdan ilki olan "başarılmış deneyimlerin transfer edilmesi", risk alma davranışı ve öz yeterlik kavramının ilişkin farklı kuram ve modellerle açıklanmaktadır. Bu konuda en çok bilinen Macera Deneyim Paradigması (Martin ve Priest, 1986), Akış (flow) durumu fikrine dayanan (Csikszentmihalyi, 1992) ancak özel olarak doğa ve macera etkinliklerine katılan bireylerin algıladıkları risk ve etkinliğe ilişkin bireysel yeterlilik dengelerine odaklanan bir modeldir (Martin ve Priest, 1986; Llewellyn ve diğ. 2008; Priest \& Gass, 2018). Katılımcıların risk ve bireysel yetkinlik algıları, maceracıların "çevreyi (doğal ve sosyal) etkileme veya kontrol altında tutabilme yeteneklerini” ne kadar iyi gösterebildiklerine bağlıdır. Paradigmaya göre deneyimsiz katılımcılar etkinliği tehlikeli ve yüksek riskli algılarken deneyimliler, temel becerilerden çok daha karmaşık görünen becerilere sahip olduklarını düşündüklerinden, etkinlikteki riskleri ve tehlikeleri daha düşük algılamaktadırlar. Çünkü doğada yaşanabilecek zorlukları yenmelerine engel olan korkuların üstesinden gelebilmektedirler. Bu sayede yaşamı sürdürmenin kritik anlarında dikkat ve eylemlere odaklanabilmeyi sağlayan bir tür zihinsel dayanıklılık kazanmış ve bilişsel kontrol uygulama becerisi geliştirmişlerdir (Llewellyn ve diğ. 2008; Priest \& Gass, 2018). Etkinliklerden sağlanan deneyim yeni bilgilerde uzmanlaşma anlamına gelir ve görevlerin başarıyla tamamlanması durumlarda başlar. Katılımcı, bir durumdaki problemi çözdüğünde takımın bir parçası olduğu ve öz değerleriyle ilgili pozitif duygular hissederek ödüllendirilmiş olur. Bu uzmanlık gelişiminin ardında yatan amaç, başarılı stratejileri genellemek ve duyguları başka durumlarla ilişkilendirmektir. Çünkü transfer macera programlarının en kritik özelliklerinden biridir. Dolayısıyla görünüşte hedef ve amaçları farklı olan etkinlikler katılımcıların öz niteliklerini geliştirmek üzere yapılandırılabilirler. Dolayısıyla yabanıl ortamlardaki macera 
deneyimlerinde, etkin bilişsel yeniden yapılandırmaya izin vermek için etkinlikler sistematik olarak tasarlanabilir. Bunun sonucunda yeni oluşturulan kodlar, farklı performans becerilerini içerebilir, ancak benzer genel becerilerin kullanımını gerektirebilir. Bir başka söylemle kış şartlarında yaşamı sürdürme becerisini sergileyerek başarılı olan bir bireyin kazanacağı öz-yeterlik, farklı bir beceriye ilişkin yeni belirlenecek kodlara etki edebilir (Taniguchi, 2017) ya da dağcılık eğitiminde edinilen deneyim eleştirel düşünce ve risk alma eğilimleri üzerinde etki yaratabilir. Çünkü yeni öğrenilecek her iki etkinlikte de bireylerin algılanan risklerle ilişkili stres ve korkularını yönetmeleri gerekmektedir. Birey yeni bir aktivite veya beceri alanını öğrenmede başarılı olduğu için, ustalık duygusu, birey yeni becerilere yaklaştığında kalıcılığı ve çabayı artıracaktır. (Bandura, 1997).

Öz yeterlik ile ilgili gerçekleştirilen çalışmalar özellikle bu çalışmaların gerçekleştirilmesinde kullanılabilecek ölçme araçlarının geliştirildiği ve kendi kültürümüze uyarlama çalışmalarının yapıldığı da görülmektedir. Bu ölçme araçları incelendiğinde Akın \& Başören (2015) "Algılanan Empatik Öz-Yeterlik ve Sosyal ÖzYeterlik", Aksoy \& Diken (2009) "Rehber Öğretmen Özel Eğitim Öz Yeterlik”, Aksoy (2008) "Rehber Öğretmen Özel Eğitim Öz Yeterlik" Koyuncu ve diğ. (2017) "Matematiksel Modelleme Yeterlikleri İçin Öz-Yeterlik", Avcı (2011) "Karakter Eğitimine İlişkin Öz-Yeterlik", Kasalak (2017) "Blok Temelli Öz-Yeterlik", Adadıŏlu \& Oğuz (2017) "Epilepsi Öz Yeterlik", Işıksal \& Aşgar (2003) "Bilgisayar Öz-Yeterlik", Delican (2016) "Illk Okuma Yazma Öğretimine Yönelik Öz Yeterlik”, Yıldız (2015) “Kariyer ve Yetenek Gelişimi Öz Yeterlik”, Akyıldız (2017) "Okul Müdürlerinin Program Uygulamalarını Yönetme Öz-Yeterlik Algısı", Aypay (2010) "Genel Öz Yeterlik", Aydın ve diğ (2013) "Öğretmen Adaylarının Yazılı Anlatım Öz Yeterlikleri”, Öztugan (2017) “Okul Öncesi Öğretmen Adaylarına Yönelik Öz Yeterlik İnanç”, Özlü ve diğ. (2013) "Çevre Eğitimi Öz-Yeterlik", Çelik (2013) "Cinsel Öz-Yeterlik", Köse (2007) "Öğretmen Öz-Yeterlik", Bakaç \& Özen (2015) "Materyal Tasarımı Öz Yeterlik İnancı", Şengül (2013) "Yazma Öz Yeterlikleri”, Sağlam \& Arslan (2018) “İngilizce Dil Becerileri Öz Yeterlik", Yeşilay (1996) "Genelleştirilmiş Özyetki Beklentisi" ve Karabay (2013) "Eleştirel Okuma Öz Yeterlik" ölçekleri olmak üzere daha birçok alanda uyarlama ve ölçek geliştirme çalışmalarının literatüre kazandırıldığı görülürken Spor Bilimleri ve Rekreasyon alanında kullanılabilecek Karaçam \& Pulur 
(2017) tarafından uyarlama çalışmasının yapıldığı "Hakem Öz Yeterlik” ölçeği bulunmaktadır.

Literatürde öz yeterlik ile ilgili birçok ölçek çalışmasının var olduğu görülürken serbest zaman ve rekreasyon alanında kullanılabilecek "öz yeterlik" ile ilgili ölçek ve çalışmalarının kısıtı olduğu aşikardır. Bu doğrultuda doğal alan rekreasyon etkinlerine katılan bireylerin öz yeterlik düzeylerini belirlemeye yönelik amaca özel bir ölçeğin bulunmaması araştırma için yönlendirici olmuştur. Bu bağlamda araştırmanın amacı; Mittelstaedt ve Jones (2009) tarafından geliştirilen Doğal Alan Rekreasyonu Öz-Yeterlik (ORSE) Ölçeği'nin Türk kültürü için geçerlik ve güvenirliğini test etmektir.

\section{Yöntem}

Araştırmada betimsel yöntemlerinden genel tarama modeli kullanılmıştır. Veriler farklı doğal alan rekreasyonu etkinlikleri arasından grup örnekleme yöntemiyle toplanmıştır. Bu yöntem grupların listelenmesinin zor olduğu büyük ölçekli tarama araştırmalarında tercih edilen bir örneklem türüdür (Balcı, 2009).

\section{Katılımcılar}

Araştırmanın örneklem grubunu, farklı doğal alan rekreasyonuna (dağcılık, dağ kayağı, spor tırmanış, serbest paraşüt, yamaç paraşütü, yelkenkanat, rafting, akarsu kanosu, dingin su kanosu, doğa kampçılığı, doğa yürüyüşü, yol bisikleti, dağ bisikleti, kayak, snowboard, aletli dalış, derin dalış, yelken, rüzgar sörfü, kite sörf) katılan 359 doğa sporu katıımcısı (139 kadın $\bar{x}=39.50$ ss=12.13 yaş; 220 erkek $\bar{x}=$ $41.36 \mathrm{ss}=12.05$ yaş) oluşturmuştur.

\section{Veri Toplama Araçları}

Araştırmada veri toplama aracı olarak Mittelstaedt ve Jones (2009) tarafından geliştirilen "Doğal Alan Rekreasyonu Öz Yeterlik Ölçeği (DARÖYÖ)" kullanılmıştır. DARÖYÖ'nün orijinal formu (a) haz/başarma (b) beceri/yeterlik olmak üzere toplam iki alt boyut ve 17 maddeden oluşmaktadır. Katılımcılar ölçekte yer alan her bir ifadeyi Hiç Doğru Değil (0) ve Çok Doğru (10) arasında değişen Likert tipi onlu derecelendirme skalası üzerinden işaretlemişlerdir. DARÖYÖ'nün Türk kültürüne adaptasyon çalışması sürecinde literatürden destek alınarak Güvendir \& Özkan (2015) tarafından önerilen kültürlerarası ölçek uyarlama aşamalarını içeren kontrol listesi dikkate alınmıştır. 
Ölçeğin Türk kültürü için uyarlama çalışmasına geçilmeden önce ilk olarak ölçeği geliştirenler tarafından ölçeğin kullanım izni alınmıştır. Daha sonra ölçeğin dilsel eşdeğerliğinin sağlanması için ölçekte yer alan maddeler için çeviri formu oluşturulmuştur. Oluşturulan bu formlar ile ölçeğe ait maddeler çeviri, geri-çeviri yöntemi ile İngilizcesi ana dili ile eş değer düzeyde olan 4 akademisyen tarafından Türkçe' ye çevrilmiştir. Çevirisi yapılan ölçek maddeleri bir araya getirilerek hakem değerlendirme formu oluşturulup bütün maddeler ölçek uyarlama çalışması ile ilgili yeterli bilgi ve deneyime sahip, İngilizce seviyesi yüksek 4 alan uzmanı tarafından bağımsız olarak değerlendirmesi istenmiş ve hakem formları içerisinden yer alan maddelerden en uygun olanı işaretlemeleri ve kendileri için boş bırakılan alana gerekli düzeltmeleri yazmaları istenmiştir. Bu aşama sonucunda hakemlerden elde edilen ölçek formları bir araya getirilerek tek bir Türkçe form oluşturulmuştur. Oluşturulan Türkçe form daha sonra İngilizce seviyesi yüksek ve ölçek uyarlama alanında uzman kişiler tarafından tekrar Ingilizceye çevrilmişsir. Bütün aşamalar sonucunda oluşturulan nihai formun pilot uygulaması yapılmış ve ölçek maddelerinin anlaşııırlı̆ı̆ test edilerek Türkçe formun hedef kitle için uygun özelliklere sahip olup olmadığı ve dil anlatımı bakımından bir sorun olup olmadığı değerlendirilmiş ve ölçeğin uygulama formuna son şekli verilerek hedef kitleye uygulatılmak üzere diğer adımlara geçilmiştir.

\section{Verilerin Analizi}

Verilerin analizinde SPSS 20 ve AMOS 23 istatistiksel paket programları kullanılmıştır. Orijinal formda yer alan 2 faktörlü 17 maddelik yapı Türk kültürü için adaptasyon çalışmasında ilk olarak ölçek maddelerine ilişkin normallik varsayımları (çarpıklık ve basıklık değerleri), madde analizleri, Açımlayıcı Faktör Analizi (AFA) ve Doğrulayıcı Faktör Analizi (DFA) yöntemleri kullanılmıştır. Ölçeğin yapı geçerliği çalışmalarından sonra Türkçe formunun güvenirliğini test etmek için Cronbach's Alpha iç tutarlık katsayısı, iki yarı test güvenirliği (Split-Half) ve madde-alan korelasyonları hesaplanmıştır.

\section{Bulgular}

\section{Yapı Geçerliği}

Yapı geçerliği analizinin ilk aşaması olan örneklemin veri analizine uygunluğu belirlenmiştir. Bunun için KMO (Kaiser-Meyer-Olkin) ve Barlett Sphericity testlerinden 
yararlanılmıştır. Analiz sonuçlarına göre KMO örneklem uygunluğu katsayısının 0.92 ve Barlett Sphericty test değerinin 3261,573 $(p<.000, d f=136)$ referans değerler içerisinde yer alması verilerin faktör analizi için uygun olduğunu göstermektedir (Field, 2009). Örneklemin veri analizi uygunluğunun test edilmesinden sonra orijinal formunda 2 faktörlü 17 madde olan DARÖYÖ'nün faktör yapısının Türk kültürü için hangi yapıda olduğunun tespit edilebilmesi için Açımlayıcı Faktör Analizi (AFA) yapılmıştır. AFA analizinde yöntem olarak tek "Temel Bileşenler Analizi” ve döndürme tekniği olarak "Varimax" seçilmiştir.

Tablo 1. DARÖYÖ Faktör Yapısı ve Faktör Yükleri

\begin{tabular}{|c|c|c|c|c|}
\hline Madde Numarası & $\begin{array}{c}\text { Faktör } 1 \\
\text { haz/başarma }\end{array}$ & $\begin{array}{c}\text { Faktör } 2 \\
\text { beceri/yeterlik }\end{array}$ & $\begin{array}{l}\text { Faktörlerin } \\
\text { Açıkladığı } \\
\text { Varyans \% }\end{array}$ & $\begin{array}{c}\text { Açıklanan } \\
\text { Toplam } \\
\text { Varyans \% }\end{array}$ \\
\hline Madde 12 & .872 & & \multirow{7}{*}{$\% 39.94$} & \multirow{13}{*}{$\% 67.77$} \\
\hline Madde 15 & .842 & & & \\
\hline Madde 17 & .825 & & & \\
\hline Madde 16 & .817 & & & \\
\hline Madde 11 & .814 & & & \\
\hline Madde 14 & .795 & & & \\
\hline Madde 13 & .791 & & & \\
\hline Madde 6 & & .802 & \multirow{6}{*}{$\% 27.82$} & \\
\hline Madde 3 & & .755 & & \\
\hline Madde 1 & & .754 & & \\
\hline Madde 4 & & .724 & & \\
\hline Madde 5 & & .683 & & \\
\hline Madde 2 & & .599 & & \\
\hline
\end{tabular}

Tablo 1 değerlendirildiğinde, Doğal Alan Rekreasyonu Öz Yeterlik Ölçeğinin (DARÖYÖ) Türkçe formunda yer alan alt boyutların orijinal form ile tutarlı olarak iki faktör altında toplandığı görülmektedir. Faktörler incelendiğinde 7,8 ve 9. Maddelerin orijinal ölçekte yer alan ilgili faktör altında toplanmaması ve yüklendiği faktör altında kuramsal ve yapısal olarak adlandırılmasının uygun olmadığı düşünülerek bu maddeler ölçekten çıkarılmış ve AFA analizi tekrarlanmıştır. Sonuç olarak maddelerin yüklendiği faktörlerin kuramsal ve yapısal olarak orijinal formla uyumlu olduğu ve faktörler altında yer alan maddelerin ".59 -.87" aralığında yer aldığı ve yüksek faktör yüklerine sahip olduğu görülmektedir. Maddelerin açıklandığı toplam varyans ise \% 67.77 olduğu belirlenmiştir. Bu sonuçlar DARÖYÖ’nün iki faktörlü yapıyı desteklediğini göstermektedir. Ayrıca DARÖYÖ'nün faktör yapısı Şekil 1'de sunulmuştur. 


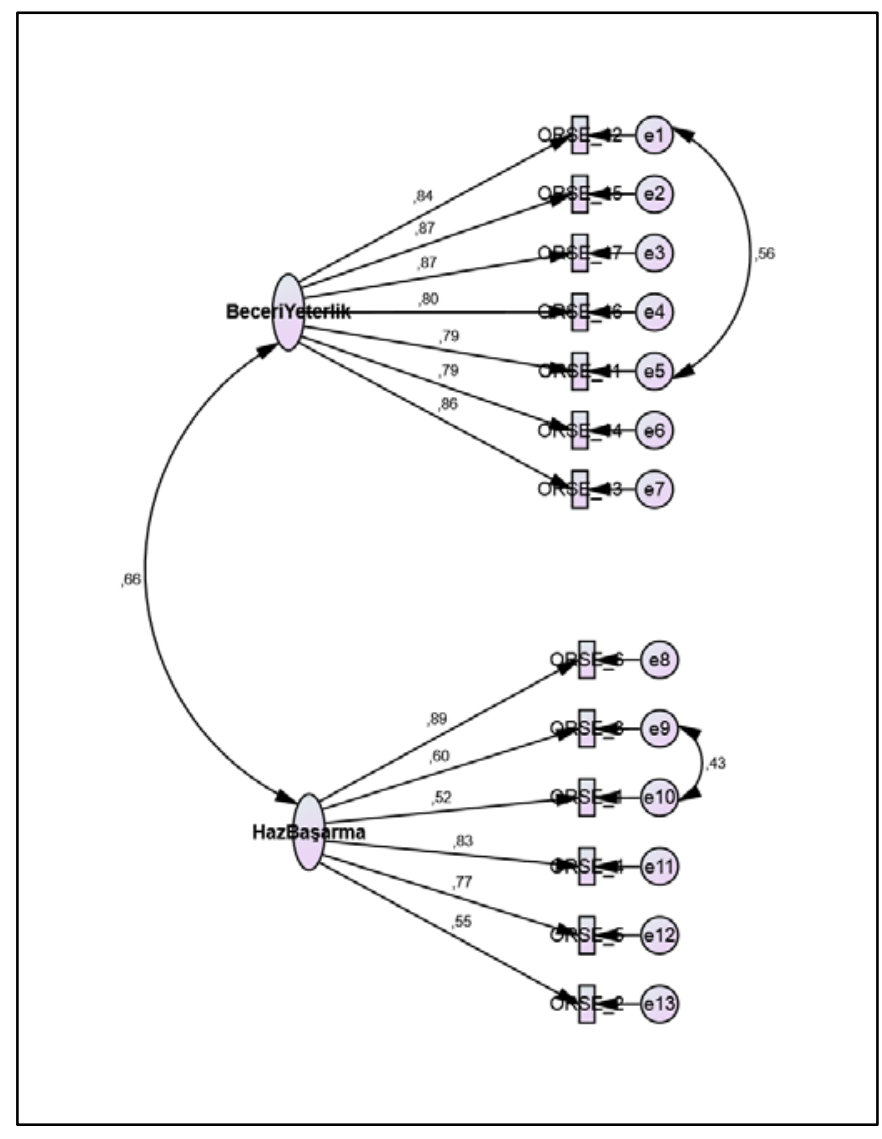

Şekil 1. DARÖYÖ’nün Faktör Yapısı

Tablo 2. DARÖYÖ'nün Model Veri Uyum Değerleri

\begin{tabular}{|l|l|l|l|l|l|l|l|l|l|}
\hline $\begin{array}{l}\text { UYUM } \\
\text { MODELLERi }\end{array}$ & x2 & Df & x'/sd & AGFI & CFI & NFI & TLI & GFI & RMSEA \\
\hline $\begin{array}{l}\text { Modifikasyon } \\
\text { Öncesi }\end{array}$ & 273.3 & 64 & 4.27 & .80 & .91 & .89 & .89 & .86 & .11 \\
\hline $\begin{array}{l}\text { Modifikasyon } \\
\text { Sonrası }\end{array}$ & 147.6 & 62 & 2.38 & .87 & .96 & .94 & .95 & .91 & .07 \\
\hline
\end{tabular}

Tablo 2 incelendiğinde, DARÖYÖ'nün iki faktörlü yapısını doğrulamak amacı ile gerçekleştirilen analiz sonuçlarına değerlendirildiğinde modelin ilk hali ile yeterli uyum düzeyine ulaşmadığı görülmüştür. Literatürde sıklıkla kullanılan ve Hoe (2008) ve Arbuckle (2012) önerilen program tarafından araştırmacının dikkat etmesi gerektiği konusunda düzeltme uyarıları verilmektedir. Bu doğrultuda kuramsal ve yapısal temeli bozmadan modele ilişkin modifikasyon indekslerine (MI) bakılmıştır. Hata terimleri temelinde oluşturulan modele ilişkin modifikasyon önerileri incelendiğinde e1-e5, e9-e10 hata terimleri arasında kovaryans oluşturulmuştur. Gerekli modifikasyon işlemlerinden sonra DARÖYÖ'nün iki faktörlü ve 13 maddelik yapısının 
kabul edilebilir ile mükemmel uyum indeksleri içerisinde yer aldığı ve maddelerin faktör yük değerlerinin .52 ile .89 arasında değiştiği görülmektedir. Buna göre DARÖYÖ'nün iki faktöllü yapısının doğrulandığı görülmektedir.

\section{Güvenirlik}

DARÖYÖ'nün güvenirliği Cronbach's Alpha ve iki yarı test (Split-Half) yöntemleriyle hesaplanmıştır. Tablo 3 de DARÖYÖ'nün güvenirlik değerleri alt boyutlar altında yer alan madde içerikleri verilmiştir. Elde edilen verilere göre ölçek alt boyutlarının Cronbach's Alpha katsayısı "beceri ve yeterlik" alt boyutu için .93, "haz ve başarma" alt boyutu için .83 olarak hesaplanırken; Spearman ve Guttman korelasyon değerleri de ölçeğe ilişkin tek sayılı madde numaraları ile formül aracılığı yapılan hesaplama sonucunda Spearman değeri .80, Guttman değeri .79; çift sayılı madde numaralarında ise Spearman değeri .82, Guttman değeri .79 olarak hesaplanmıştır.

Tablo 3. DARÖYÖ'nün Güvenirlik Değerleri, Madde Numaraları ve İçerikleri

\begin{tabular}{|c|c|c|c|c|c|}
\hline & & & $\alpha$ & & \\
\hline \multirow{2}{*}{$\begin{array}{l}\text { DARÖY } \\
\text { Ö }\end{array}$} & $\begin{array}{l}\text { Beceri } \\
\text { ve } \\
\text { Yeterlik }\end{array}$ & $\begin{array}{l}\text { 12-Becerikli hissediyorum. } \\
\text { 15-Başarılı olduğumu } \\
\text { hissediyorum. } \\
\text { 17-Başarabileceğime } \\
\text { inanıyorum. } \\
\text { 16-Yeterli olduğumu } \\
\text { düşünüyorum. } \\
\text { 11-Yetkin hissediyorum. } \\
\text { 14-Yetenekli hissediyorum. } \\
\text { 13-Kendime güveniyorum. }\end{array}$ & $\begin{array}{l}.9 \\
3\end{array}$ & & \\
\hline & $\begin{array}{c}\text { Haz ve } \\
\text { Başarm } \\
\text { a }\end{array}$ & $\begin{array}{l}\text { 6-Zevk alıyorum. } \\
\text { 3-Eğleniyorum. } \\
\text { 1-Hoşça vakit geçiriyorum. } \\
\text { 4-Enerjik hissediyorum. } \\
\text { 5-Yapmakta olduğum şeyle } \\
\text { gerçekten ilgileniyorum. } \\
\text { 2-Heyecanlanıyorum. }\end{array}$ & $\begin{array}{l}.8 \\
3\end{array}$ & & \\
\hline & & & & $\begin{array}{l}\text { Spearma } \\
\text { n-Brown }\end{array}$ & Guttman \\
\hline İlk Yarı T & Sayılı Ma & de Numaraları & & .80 & .79 \\
\hline İkinci Ya & ift Sayılı & adde Numaraları & & .82 & .78 \\
\hline
\end{tabular}




\section{Tartışma ve Sonuç}

$\mathrm{Bu}$ araştırmanın amacı, Mittelstaedt ve Jones (2009) tarafından geliştirilen Doğal Alan Rekreasyonu Öz-Yeterlik Ölçeği (DARÖYÖ)"nin Türk kültürü için geçerlik ve güvenirliğini test etmektir. Ölçek uyarlama ile ilgili gerekli prosedürler sırası ile tamamlandıktan sonra oluşturulan nihai form doğa sporları ile uğraşan çeşitli kategoriler altında yer alan katılımcılara uygulanmıştır. Ölçek formunun orijinali iki faktör ve toplam 17 maddeden oluşan DARÖYÖ'nin Türk kültürü için faktör yapısının belirlenebilmesi amacı ile gerçekleştirilen madde analizleri, AFA ve DFA sonuçları, ölçeğin orijinali ile tutarlı olarak iki faktörlü yapı ve azaltılmış madde sayısı ile doğrulandığını göstermiştir. AFA sonrasında elde edilen bulgular incelendiğinde ölçeğin iki faktörlü yapı altında toplandığı ancak bazı maddelerin (madde 7,8,9) ilgili faktör altında yüklenmediği gözlemlenerek kuramsal ve yapısal olarak maddelerin isimlendirilememesi sebebi ile bu maddeler ölçekten çıkarılarak AFA analizi tekrarlanmıştır. AFA analizi sonrasında iki faktör ve 13 madde olarak belirlenen maddelerin yüklendiği faktörlerin kuramsal ve yapısal olarak orijinal formla uyumlu, yüksek faktör değerlerine (.59 - .87 aralığında) sahip olduğu ve toplam varyansın \% 67.77 ile açıklandığı belirlenmiştir. Bu oranla \%74,54'lük (Mittelstaedt ve Jones, 2009) orijinal formdan daha düşük bir varyans temsiline karşın yüksek bir temsiliyete sahiptir. Yapının doğrulanması amacı ile gerçekleştirilen DFA sonrasında yapıya ilişkin uyum değerlerinin istenilen düzeyde olmadığı görülmüştür. Bu doğrultuda Hoe (2008) ve Arbuckle (2012) tarafından önerilen program tarafından gösterilen bir takım modifikasyon indekslerine bakılarak model üzerinde gerekli iyileştirmeler yapılmıştır. Modifikasyon sonrasında bütün değerlerin iyi/kabul edilebilir düzeyde olduğu görülmüştür. Araştırmadan elde edilen bu bulgular, ölçeğin orijinal formunun faktör yapısı ile Türk kültürü için yapısı araştırılan formun faktör yapısının örtüştüğü görülmektedir. Faktör analizi sonucunda yapısı belirlenen ölçeğin alt boyutlarından elde edilen Cronbach's Alpha iç tutarlık katsayısı "beceri ve yeterlik" alt boyutu için .93, "haz ve başarma" alt boyutu için .83 olarak hesaplanmıştır. Ölçeğin uygulama kolaylığı ve zaman tasarrufu açısından test-tekrar test güvenirliği yerine iki yarı test güvenirlik değerleri hesaplanmıştır. Bu doğrultuda elde edilen sonuçlara göre ölçeğin tek sayılı madde numaralarından elde edilen Spearman ve Guttman korelasyon değerleri sırası ile .80 ve .79; çift sayılı madde numaralarından elde edilen değerleri ise .82 ve .79 olarak hesaplanmıştır. 
Literatür incelendiğinde özellikle doğal alan rekreasyonuna yönelik çalışan araştırmacıların ve çalışmaların sayıca az olduğu görülmektedir. Bu doğrultuda araştırma kapsamında Türk kültürü için uyarlama çalışması yapılan DARÖYÖ'nin özellikle yurtiçi literatüründe önemli bir boşluğu dolduracağı düşünülmektedir. Ölçeğinin ulusal literatürdeki kullanımı, rekreasyon araştırmacıları ve uygulayıcıları tarafından çeşitli ortamlarda önemli ve değerli bir katkıyı temsil eden kritik öneme sahip bir çabadır. Ölçek doğal alan rekreasyonu temelli programların, derslerin, atölye çalışmalarının ve etkinliklerin önemli etkisini belgelemek için güvenilir bir yöntem sağlayan çok intiyacı karşılayacak bir araçtır. Ayrıca DARÖYÖ ile yapılacak çalışmalardan elde edilecek sonuçlardan doğal alan rekreasyonu ile uğraşan katııımcılara ve antrenörlere katkı sağlayacağı düşünülmektedir. Sonuç olarak, doğal alan rekreasyonuna yönelik etkinliklere katılımına yönelik durumsal değişken olarak görülebilecek öz yeterlik algısının etkinlik çeşitlerine göre ölçülmesi için Doğal Alan Rekreasyonu Öz Yeterlik Ölçeği'nin geçerli ve güvenilir bir ölçme aracı olarak kullanılabileceği düşünülmektedir.

\section{Kaynaklar}

Adadıoğlu, Ö. \& Oğuz, S. (2017). Epilepsi Öz Yeterlik Ölçeği Geçerlik ve Güvenirlik Çalışması. Aydın: Adnan Menderes Üniversitesi 1. Uluslararası Sağlık Bilimleri Kongresi: 679.

Akın, A. \& Başören, M. (2015). Algılanan Empatik Öz-Yeterlik ve Sosyal Öz-Yeterlik Ölçeği' nin Türkçe Formunun Geçerlik ve Güvenirliği. Bartın Üniversitesi Eğitim Fakültesi Dergisi. 4(2): 603-610. doi.org/10.14686/buefad.v4i2.1082000235

Aksoy, V. \& Diken, İ., H. (2009). Rehber Öğretmen Özel Eğitim Öz Yeterlik Ölçeği: Geçerlik ve Güvenirlik Çalışması. Ankara Üniversitesi Eğitim Bilimleri Fakültesi Özel Eğitim Dergisi. 10(1): 29-37. doi.org/10.1501/Ozlegt_0000000131

Aksoy, V. (2008). Rehber Öğretmenlerin Özel Eğitimde Psikolojik Danışma ve Rehberliğe İlişkin Öz Yeterlik Algıları (Yüksek Lisans Tezi). Anadolu Üniversitesi Eğitim Bilimleri Enstitüsü. Eskişehir.

Akyıldız, S. (2017). Okul Müdürlerinin Program Uygulamalarını Yönetme Öz-Yeterlik Algısı Ölçeği: Geçerlik ve Güvenirlik Çalışması. Ahi Evran Üniversitesi Kırşehir 
Eğitim Fakültesi Dergisi (KEFAD). 18(2): 401-418. doi.org/10.29299/ kefad.2017.18.3.025

Arbuckle, J., L. (2012). IBM SPSS Amos 19 User's Guide. uww.amosdevelopment.com/download/amos.pdf

Avcı, E. (2011). İlköğretim Sosyal Bilgiler Öğretmenlerinin Karakter Eğitimine Dair Öz-Yeterliklerinin İncelenmesi (Doktora Tezi). Gazi Üniversitesi Eğitim Bilimleri Enstitüsü. Ankara.

Aydın, İ. S., İnnalı, H. Ö. Batar, M. \& Çakır, H. (2013). Öğretmen Adaylarının Yazılı Anlatım Öz Yeterliklerine İlişkin Ölçek Geliştirme Çalışması. Turkish Studies. 8(8):139-160. https://doi.org/10.7827/TurkishStudies.4978

Aypay, A. (2010). Genel Öz Yeterlik Ölçeği' nin GÖYÖ Türkçe' ye Uyarlama Çalışması. İnönü Üniversitesi Eğitim Fakültesi Dergisi. 11(2):113-131.

Bakaç, E. \& Özen. R. (2015). Materyal Tasarımı Öz-Yeterlik İnancı Ölçeği: Geçerlik ve Güvenirlik Çalışması. Int. Journal of Human Sciences. 12(2):461-476. doi.org/10.14687/ ijhs.v12i2.3341

Balcı, A. (2009). Sosyal Bilimlerde Araştırma Yöntem Teknik ve İlkeler (7. Baskı), Ankara: Pegem Akademi.

Bandura, A. (1977). Self-Efficacy: Toward A Unifying Theory of Behavioral Change. Psychological. (84):191- 215. doi.org/10.1037// 0033-295X.84.2.191

Bandura, A. (1990). Perceived Self-Efficacy in The Exercise of Personal Agency. Journal of Applied Sport Psychology. (2):128-163. doi.org/10.1080/10413209008406426

Bandura, A. (1997). Self-Efficacy: The Experience of Control. New York: WH.

Bell, S. (1997). Design For Outdoor Recreation. (First Edition). London:1 doi.org/10.4324/9780203362334

Csikszentmihalyi, M. (1992). Imagining The Self: An Evolutionary Excursion. Poetics. 21(3): 153-167. doi.org/10.1016/0304-422X(92)90002-K

Cordell, H., K. (2008). Nature-based outdoor recreation trends and wilderness. International Journal of Wilderness, 14(2), 7-13.

Çelebi, M. (2002) Doğa Eğitimi Etkinliklerinin. Liderlik Becerilerinin Ortaya Çıkarılmasındaki Rolü. Eğitim Yönetimi Programı Doktora Tezi. Abant İzzet Baysal Üniversitesi Sosyal Bilimler Enstitüsü. 
Çelik, E. (2013). Cinsel Öz-Yeterlik Ölçeğinin Türk Kültürüne Uyarlanması: Geçerlik ve Güvenirlik Çalışması. Journal Of European Education. 3(2):1-10.

Delican, B. (2016). İlk Okuma Yazma Öğretimine Yönelik Öz Yeterlik Ölçeğinin Geliştirilmesi. Turkish Studies. 11(3):861-878. doi.org/10.7827/ Turkish Studies.9277

Demirhan, G. (1995). Sporda Becerileri Öğreniminde Merkezli Yönetimi Erişi ve Kalıcılığa Etkisi Eğitim Programları ve Öğretim Bilim Dalı Doktora Tezi. Hacettepe Üniversitesi Sosyal Bilimler Enstitüsü. Ankara.

Duman, B., A. (2007). Lise Öğrencilerinin İngilizceye Yönelik Öz Yeterlik Algı Puanlarının Cinsiyete. Alanlara ve Farklı Düzeylere Göre İngilizce Başarısını Yordama Gücü. (Yüksek Lisans Tezi). Yıldız Teknik Üniversitesi. Sosyal Bilimler Enstitüsü.

Ewert, A.W. \& Sibthorp, J. (2014) Outdoor Adventure Education : Foundation, Theory, and Research; Human Kinetics, Champaign IL.

Ewert, S. \& Hollenhorst (1989) Testing The Adventure Model: Empirical Support For A Model of Risk Recreation Participation. Journal of Leisure Research pp.124139. doi.org/10.1080/00222216.1989.11969794

Field, A. (2009). Discovering Statistic: Using SPSS. Sage: Los Angeles.

Güvendir, M., A. \& Özkan, Y. Ö. (2015). Türkiye'deki Eğitim Alanında Yayımlanan Bilimsel Dergilerde Ölçek Geliştirme ve Uyarlama Konulu Makalelerin İncelenmesi. E-Sosyal Bilimler Dergisi. 14 (52): 23-33.

Haegeli, P. \& Pröbstl-Haider, U. (2016). Research on Personal Risk in Outdoor Recreation and Nature-Based Tourism. Journal of Outdoor Recreation and Tourism 13: 1-9. doi.org/10.1016/j.jort.2016.02.001

Hoe, S., L. (2008). Issues and Procedures in Adopting Structural Equation Modeling Technique. J. of Applied Quantitative Methods. 3(1). 76-83.

Işıksal, M. \& Aşkar, P. (2003). İlköğretim Öğrencileri İçin Matematik ve Bilgisayar ÖzYeterlik Algısı Ölçekleri. Hacettepe Ünv. Eğitim Fakültesi Dergisi. (25): 109118.

Jones, J. J., \& Hinton, J. L. (2007). Study of Self-Efficacy in Freshman Wilderness Experience Program: Measuring General Versus Specific Gains. Journal of Experiential Education, Symposium on Experiential Education Research 29(3), 382-385. doi.org/10.1177/105382590702900311 
Karabay, A. (2013). Eleştirel Okuma Öz Yeterlik Algı Ölçeğinin Geliştirilmesi. ETurkish Studies. 8(13):1107-1122. doi.org/10.7827/ TurkishStudies.5389

Karaçam, A. \& Pulur, A. (2017). Hakem Öz Yeterlik Ölçeği'nin (HÖYÖ) Türkçeye Uyarlama Çalışması. Niğde Üniversitesi Beden Eğitimi ve Spor Bilimleri Dergisi.11(1):118-128.

Karaküçük, S. (2014). Rekreasyon Boş Zamanları Değerlendirme. Seren Matbacılık. Ankara.

Karaküçük, S. Ardahan, F., Çetinkaya, G., Akgül, B., M. \& Kalkan, A.,K. (2017) Açık Alan Rekreasyonu (Edt: Ardağan, F.), Detay Yayıncılık.

Kasalak, ì. (2017). Robotik Kodlama Etkinliklerinin Ortaokul Öğrencilerinin Kodlamaya İlişkin Öz-Yeterlik Algılarına Etkisi Ve Etkinliklere İlişkin Öğrenci Yaşantıları (Yüksek Lisans Tezi). Ankara: H.Ü. Eğitim Bilimleri Enstitüsü.

Koyuncu, I., Güzeller, C., O. \& Akyüz, D. (2017). The Development Of A Self-Efficacy

Scale For Mathematical Modeling Competencies. International Journal of Assessment Tools in Education. (4): 19-36. doi.org/10.21449/ ijate.256552

Köse, İ., A. (2007). Öğretmen Öz-Yeterlik Algısı Ölçeğinin Farklı Gruplarda Yapı Geçerliğinin Sınanması (Yüksek Lisans Tezi). Ankara Üniversitesi.

Llewellyn, D., J., Sanchez, X., Asghar. A. \& Jones, G. (2008). Self Efficacy, Risk Taking and Performance in Rock Climbing. Personality and Individual Differences. 45(1):75-76. doi.org/10.1016/j.paid.2008.03.001

Martin, B., Cashel, C., Wagstaff, M. \& Breuning M. (2006). Outdoor Leadership Theory and Practice: 8.

Martin, P. \& Priest, S. (1986). Understanding The Adventure Experience. Journal of Adventure Education. 3(1):18-21.

Mittelstaedt, R., D. \& Jones, J., J. (2009). Outdoor Recreation Self-Efficacy: Scale Development. Reliability and Validity. Journal of Outdoor Recreation. Education and Leadership. 1(1):97-120. doi.org/10.7768/1948-5123.1006

Orhun, A. (Ekim. 1994) Beden Kültüründe Paradigma Değişimi ve Okul Sporunun Yeniden Sorgulanması. Spor Bilimleri Ulusal Kongresi. Hacettepe Üniversitesi. Ankara.

Outdoor Industry Association (2013). The outdoor recreation economy 2012. CO:Boulder.https://outdoorindustry.org/resource/the-outdoor-recreation economy-2012/. 
Özlü, G., Özer, K., M. \& Gül, A. (2013). Çevre Eğitimi Öz-Yeterlik Ölçeği Geliştirilmesi: Geçerlik ve Güvenirlik Çalışması. Gazi Üniversitesi Gazi Eğitim Fakültesi Dergisi. 33(2): 393-410.

Öztugan, Y. (2017).Okul Öncesi Öğretmen Adaylarına Yönelik Öz-Yeterlik İnanç Ölçeği Geliştirme Çalışması. The Journal of Academic Social Science Studies. 3(61): 47-59. doi.org/10.9761/JASSS7313

Pajares, F. \& Schunk, D., H. (2001). Self-Beliefs And School Success: Self-Efficacy. Self-Concept And School Achievement in: Riding R. Rayner S Eds. Perception. London: Ablex Publishing: 239- 266.

Priest, S. \& Gass, A., M. (2018). Effective Leadership in Adventure Programming. Human Kinetics. Champaing.

Propst, D. B., \& Koesler, R. A. (1998). Bandura goes outdoors: Role of self-efficacy in the outdoor leadership development process. Leisure Sciences, 20, 319-344. doi.org/10.1080/01490409809512289

Pröbstl-Haider, U., Haider, W., Wirth, V. \& Beardmore, B. (2015). Will Climate Change Increase The Attractiveness of Summer Destinations In The European Alps? A Survey of German Tourists. J. of Outdoor Recreation And Tourism, 11, 44-57. doi.org/10.1016/j.jort.2015.07.003

Sağlam, D. \& Arslan, A. (2018). The Development of English Language Skills SelfEfficacy Scale For Higher Education Students. Internatıonal Journal of Psycho-Educational Sciences. 7(2): 1-15.

Schmidt, A, \& DeShon, R. (2009) Prior Performance and Goal Progress as Moderators of The Relationship Between Self-Efficacy and Performance. Human Performance, 22, 191-203. doi.org/10.1080/ 08959280902970377

Şengül, M. (2013). Ortaokul Öğrencilerine Yönelik "Yazma Öz Yeterlikleri Ölçeği" Geliştirme Çalışması. Türkiye Sosyal Araştırmalar Dergisi 17(1): 81-94.

Taniguchi, S., T., Bennion, J., Duerden, M., D., Widmer, M. A. \& Ricks. M. (2017). Self-Efficacy Of Risk Taking in Outdoor Recreation As A Predictor Of The SelfEfficacy Of Risk Taking in Essay Writing. Journal Of Outdoor Recreation. Education and Leadership. 9(4): 425-438. doi.org/10.18666/ JOREL-2017-V9$14-8653$ 
Tutar-Güven, Ş. \& İşler, A. (2015). Epilepsili Çocuklarda Nöbet Öz-Yeterlik Ölçeği Geçerlik ve Güvenirlik Çalışması. Nöropsikiyatri Arşivi. (52):47-53. doi.org/10.4274/npa.y7399

Vancouver, J.B. (2012). Rhetorical reckoning: A response to Bandura. Jounral of Management, 38(2), 465-472. doi: 10.1177/0149206311435951

Vancouver, J. B., \& Kendall, L. N. (2006). When self-efficacy negatively relates to motivation and performance in a learning context. Journal of Applied Psychology, 91, 1146-1153. doi.org/10.1037/0021-9010.91.5.1146

Yeşilay, A. (1996). Genelleştirilmiş Özyetki Beklentisi Ölçeği. http://Userpage. FuBerlin.De/ Health/Turk.Htm

Yıldız, M. (2015). Kariyer ve Yetenek Gelişimi Öz Yeterlik Ölçeği Geçerlik ve Güvenirlik Çalışması. Electronic International Journal of Education. Arts. and Science 1(2): 164-180. 